\title{
EMERGENCY ABDOMINAL ULTRASOUND AS SUFFICIENT DIAGNOSTIC MODALITY IN THE DIAGNOSIS OF BILIARY ILEUS
}

\author{
Mitrovic Milica, ${ }^{1}$ Stanisic Nevena, ${ }^{1}$ Perisic Zlatko, ${ }^{2}$ Lesevic Ivana, ${ }^{3}$ \\ Vasin Dragan, ${ }^{1}$ Doklestic Krstina ${ }^{2,3}$ \\ ${ }^{1}$ Center for Radiology and MRI, Clinical Center of Serbia, Belgrade, Serbia \\ ${ }^{2}$ Clinic for Emergency Surgery, Clinical Center of Serbia, Belgrade, Serbia \\ ${ }^{3}$ University of Belgrade Faculty of Medicine, Serbia, Belgrade, Serbia
}

Primljen/Received 25. 11. 2020. god.

Abstract: Introduction: Biliary ileus is a rare emergency condition that mainly affects the elderly population, with a predominance of females and a mortality rate of $12-27 \%$. It is a mechanical intestinal obstruction caused by the impaction of the biliary calculus within the gastrointestinal tract. It occurs due to the formation of bilio-enteric fistula, as a rare complication of cholelithiasis. Case report: A 73-year-old male patient with epigastric pain, nausea and vomiting was referred for ultrasound exam. The analysis of the clinical-biochemical status of the patient as well as the ultrasound examination of the abdomen itself raised the suspicion of small intestine obstruction, due to the enclaved biliary calculus. After an urgent exploratory laparotomy, the diagnosis was confirmed, and enterotomy was successfully performed with calculus extraction. Cholecysto-duodenal fistula has been confirmed as a major cause of biliary ileus. The post-operative course was uneventful. Conclusion: This case report highlights the enormous importance of ultrasound diagnostics in diagnosing biliary ileus using the criteria of The Rigler Triad, which includes pneumobilia, intestinal obstruction and ectopic calculus. Initially unrecognisied cause of obstruction and a late diagnosis correlated with bad prognosis. Ultrasonographic examination of these patients, can be a sufficient diagnostic modality in making an accurate diagnosis and further surgical treatment of these patients.

Keywords: cholelithiasis, biliary ileus, ultrasonographic examination of the abdomen.

\section{INTRODUCTION}

Biliary (gallstone) ileus is important, though rare, cause of mechanical intestinal obstruction. It is a infre-
Prihvaćen/Accepted 21. 12. 2020. god.

quent complication of cholelithiasis. The frequency of gallstone ileus recurrence is $4 \%$, but increases to $25 \%$ in patients older than 65 years. It is mostly a condition in the older female population (1). Ileus is caused by an impaction of a large gallstone (one or more) within the lumen of the small intestine. A gallstone passes through a fistulous tract before becoming impacted and the most common type of fistula is between the gallbladder and the duodenum (2). It can obstruct any part of the gastrointestinal tract, but most frequently affects distal ileum. The mortality rate is high and ranges from 12 to $27 \%$, because these patients are more often elderly people who have associated chronic diseases $(2,3)$.

\section{CASE REPORT}

We present a case of gallstone ileus with cholecystoduodenal fistula in a male patient as first presentation of gall stone disease. This 73-year-old male patient was admitted to the Emergency Center, Clinical Center of Serbia and presented initially with symptoms of abdominal pain, nausea, vomiting and hiccups for the last eight days. He also complained of relative constipation. On examination, painful epigastric sensitivity was found. He was hemodynamically stable without fever or jaundice. Laboratory evaluation revealed a leukocytes level of $23.5 * 109 / \mathrm{L}$. Abdominal ultrasound and upright abdominal radiography were performed. Plain radiography of the abdomen showed air-fluid levels in the epigastric area and signs of pneumobilia. Abdominal ultrasound confirmed the presence of air in the biliary tree (Figure 1A). It also showed pronounced dilation of the stomach and jejunal loops, with diameter measured about 30mm (Figure 1B, C). In the projection of the jejunum, a calculus of about 34 


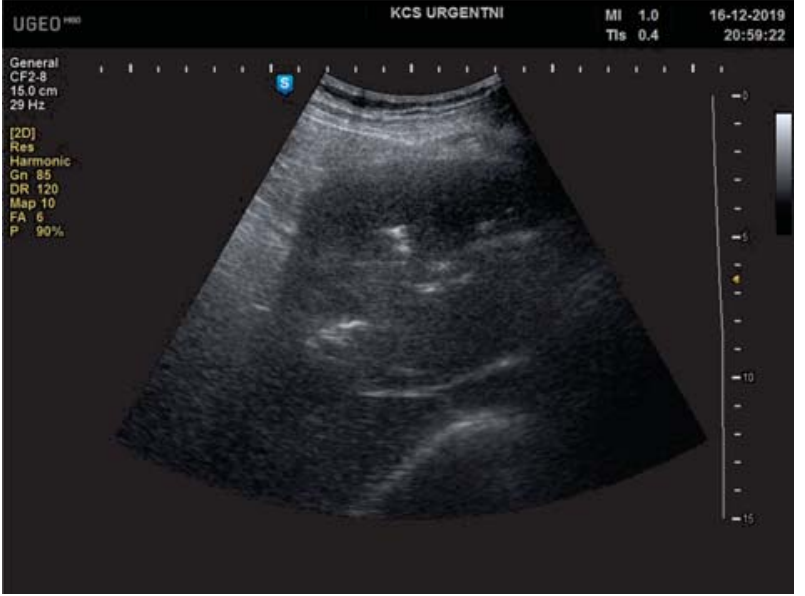

Figure 1A. Ultrasound image of the liver with focuses of high echogenicity with shadowing that suggest pneumobilia

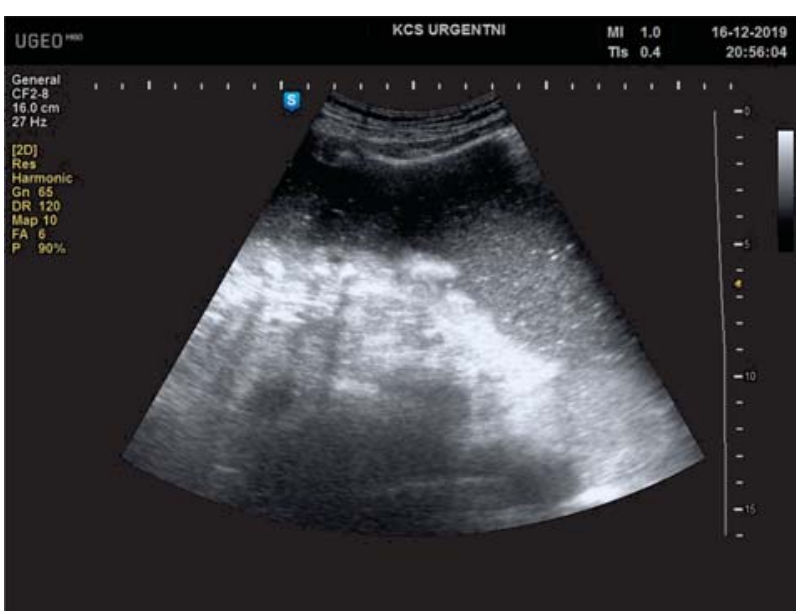

Figure 1B. Ultrasound image of the stomach with its dilatation

$\mathrm{mm}$ in diameter was detected (Figure 1D). The gallbladder was collapsed. All signs belong to the Rigler's triad (pneumobilia, ectopic gallstone, and intestinal obstruction). Ultrasound in this case was enough to make a definitive diagnosis of gallstone ileus. After urgent exploratory laparotomy, the diagnosis was confirmed. The patient was treated surgically with enterolithotomy. An ectopic gallstone was detected in distal ileum, it measured $4 \times 2 \mathrm{~cm}$ in diameter and completely occluded the lumen of the small bowel. Cholecystoduodenal fistula was revealed, without any pathological content in the cholecyst. Enterotomy was done with the extraction of calculus (Figure 2). Postoperative recovery was uneventful.

\section{DISCUSSION}

Biliary ileus is mechanical intestinal obstruction caused by the impaction of the larger calculus $(>2.5$ $\mathrm{cm}$ ), while smaller calculus is more often asymptomatic because it does not lead to obstruction and passes

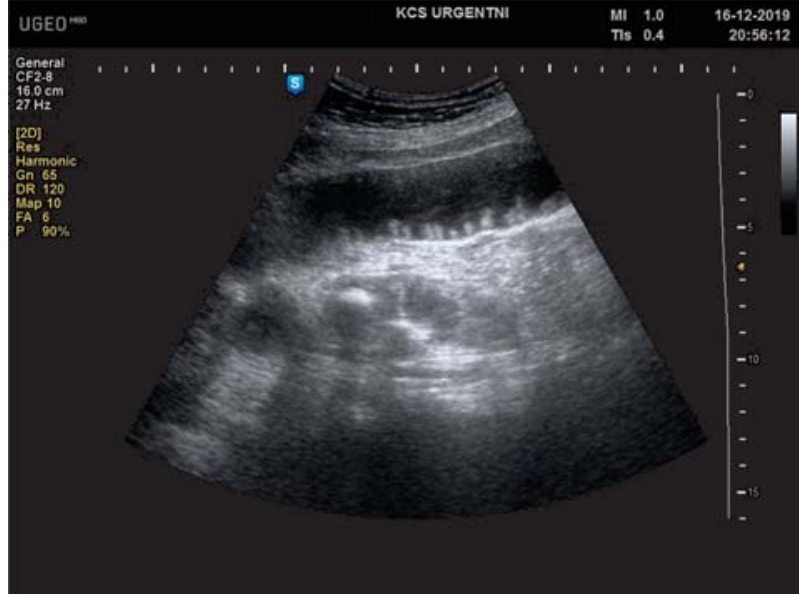

Figure 1C. Ultrasound image of dilated jejunal loops

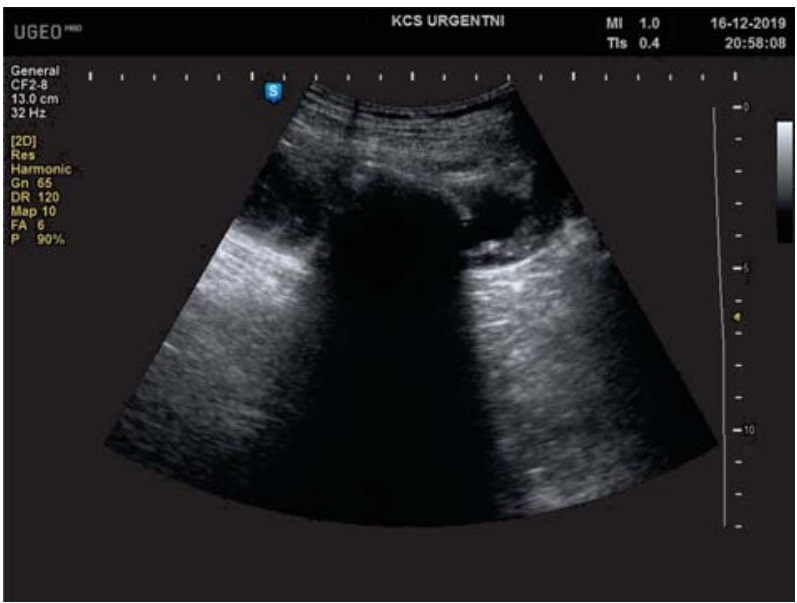

Figure 1D. Ultrasound image shows a calculus $(34 \mathrm{~mm})$ in the projection of the distal ileum

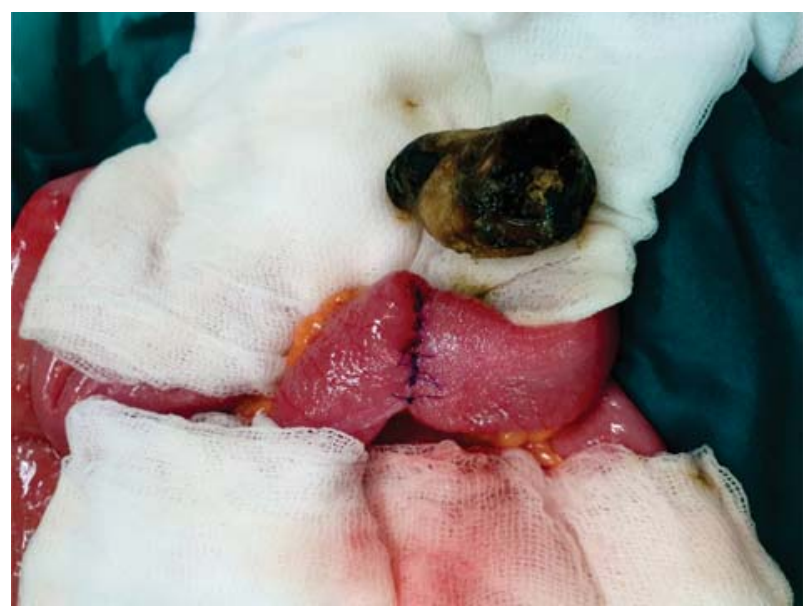

Figure 2. Intraoperative image - Enterotomy and extracted calculus $(4 \times 6 \mathrm{~cm})$

through intestinal loops like "rolling stones" $(4,5)$. A gallstone passes through a fistulous tract before becoming impacted and the most common type of fistula is between the gallbladder and the duodenum (68\%). Other possible, but less common, fistulization are cholecysto-jejunal, cholecysto-colonic (5-25\%), cholecysto- 
duodenal-colonic (2.5\%), and cholecysto-gastric fistula (5). Fistulisation is the most common but not the only possible mechanism of biliary ileus, so there are also: the passage of calculus through the ampulla of Vater, and iatrogenic causes (during ERCP or a cholecystectomy) $(5,6,7)$. It can obstruct any part of the gastrointestinal tract, but frequently at the distal ileum, ileocaecal valve in $60 \%$ of cases due to their anatomically narrow lumen. The other sites of stone impaction are jejunum $(16 \%)$, stomach $(14 \%)$, colon $(4 \%)$, and duodenum $(3.5 \%)(5,7)$. Gallstone coleus and Bouveret's syndrome are two very rare forms of biliary ileus (7). Gallstone coleus is a gallstone obstruction at the level of the colon, more often sigmoid colon (mostly in combination with diverticulitis) or transverse colon (anatomical proximity to the cholecyst). Gallstone reaches the colon by passing through the ileocecal valve or by direct fistulization with the loops of the colon $(8,9)$. Bouvert's syndrome is a very rare form of biliary ileus in which the obstruction is at the level of the distal stomach or proximal duodenum, and mostly with calculus larger than $2.5 \mathrm{~cm}$ (10).

The symptoms and signs of gallstone ileus are mostly nonspecific. The onset of the presentation can be acute, subacute, or chronic. Gallstone ileus frequently clinically manifests as abdominal pain, nausea, vomiting, fever, distension, and constipation. The character of vomiting depends on the location of the obstruction (6). At the time of intestine obstruction $10-30 \%$ of patients have acute cholecystitis. The "tumbling phenomenon", partial obstruction or distal migration of the gallstone may be the cause of why the patient usually present at hospital 4 to 8 day after the beginning of symptoms $(6,7)$.

Plain abdominal film radiography is usually the first and significant step in diagnosing intestine obstruction regardless of the cause. The advantage is that it is a quick and easy diagnostic test. The sensitivity of plain abdominal film radiography for the diagnosis of gallstone ileus is between 40 and $70 \%$ (2). It is very difficult to detect the calculus itself in the case of biliary ileus on plain abdominal film radiography, because it requires that the gallstone contain enough calcium, which occurs in only $10-20 \%$ of cases. Another important sign that can be detected on plain abdominal film radiography is pneumobilia, which is specific but not pathognomonic for biliary ileus $(5,6)$.

The Rigler triad consists of pneumobilia, intestinal obstruction and ectopic gallstone. The presence of two signs of Rigler'striad, has been considered pathognomonic in $20 \%-50 \%$ of cases $(6,7)$.

When it comes to diagnosing gallstone disease, abdominal ultrasonography has proven to be the most effective method, with an efficiency of more than $95 \%$ (7). It is a low-cost, non-invasive and fast diagnostic procedure. Disadvantages are limited visualization at patients with ileus due to discomfort and intestine loops with gas or fluid, as well as dependence on the skill of the sonographer. When it comes to an experienced sonographer, it is possible to detect the signs of the $\mathrm{Ri}$ gler's triad with the precise location of the gallstone. The combination of abdominal films and ultrasound imaging has a sensitivity of diagnosis of gallstone ileus up to $74 \%(1,7,10-13)$.

Computed tomography is a diagnostic method that is considered the gold standard in diagnosing biliary ileus. This is supported by the high sensitivity of $\mathrm{CT}$ in the detection of the exact location of the obstruction, as well as a more precise measurement of the size of the ectopic calculus. On the other hand, a high dose of radiation is used and a numerous unwanted effects on the application of iodinated contrast media are possible. Therefore, the optimal diagnostic plan could be the primary application of abdominal ultrasound and then, but in case of non-inclusiveness of the findings, in further diagnostic protocol CT exam should be applied $(11,12,13)$.

The surgical approach is something that is still being researched. The goal is to resolve the obstruction while reducing the risk of developing complications. Surgical modalities used today are enterolithotomy, enterolithotomy with later cholecystectomy and one-stage surgery that includes enterolithotomy, cholecystectomy and fistula repair (14).

Several factors should be considered when choosing a surgical treatment. Enterotomy at the antimesenteric border with removal of the calculus and transverse closure is first option. Clinically stable patients are main candidates for one-stage surgery. Enterolithotomy alone is the most commonly used surgical option, due to the lowest risk of complications $(14,15)$. When surgical treatment is contraindicated, endoscopic mechanical lithotripsy handling fragmentation is sometimes possible (15).

Biliary ileus is a rare emergency condition that mainly affects the elderly population, with a predominance of females and a mortality rate of $12-27 \%$. Initially unrecognized cause of obstruction and delayed diagnosis correlate with a worse prognosis. The presentation of this case indicates the enormous importance of a detailed and comprehensive ultrasonographic examination of these patients, which is quite a sufficient diagnostic modality in making an accurate diagnosis and further surgical treatment of these patients.

\section{Abbreviations}

ERCP - Endoscopic Retrograde CholangioPancreatography

CT - Computed Tomography 


\section{Acknowledgements}

Conceptualization, M.M., D.V.; methodology, Z.P., I.L.; resources N.S., M.M.; writing and editing M.M ., D.V.; supervision D.V., K.D.;

Conflict of Interests: The authors declare that there are no conflicts of interest related to this article.

Funding: None

\section{Ethics statements and consent:}

Patient details have been de-identified such that patien's identity remains anonymous, and we obteined verbal consent from the patient to publish the case report.

\section{Licensing}

This work is licensed under a Creative Commons Attribution 4.0 International (CC BY 4.0) License.

\title{
Sažetak
}

\section{ULTRASONOGRAFSKI PREGLED ABDOMENA KAO DOVOLJAN DIJAGNOSTIČKI MODALITET U POSTAVLJANJU DIJAGNOZE BILIJARNOG ILEUSA - PRIKAZ SLUČAJA}

\author{
Mitrovic Milica, ${ }^{1}$ Stanisic Nevena, ${ }^{1}$ Perisic Zlatko, ${ }^{2}$ Lesevic Ivana, ${ }^{3}$ \\ Vasin Dragan, ${ }^{1}$ Doklestic Krstina ${ }^{2,3}$ \\ ${ }^{1}$ Center for Radiology and MRI, Clinical Center of Serbia, Belgrade, Serbia \\ ${ }^{2}$ Clinic for Emergency Surgery, Clinical Center of Serbia, Belgrade, Serbia \\ ${ }^{3}$ University of Belgrade Faculty of Medicine, Serbia, Belgrade, Serbia
}

Uvod: Bilijarni ileus je retko urgentno stanje koje zahvata uglavnom stariju populaciju, sa predominacijom osoba ženskog pola i stopom smrtnosti $12-27 \%$. Predstavlja mehaničku intestinalnu opstrukciju uzrokovanu impakcijom bilijarnog kalkulusa unutar gastrointestinalnog trakta. Nastaje usled formirane bilio-enterične fistule, kao retka komplikacija holelitijaze.

Prikaz slučaja: Pacijent muškog pola, star 73 godine, sa bolnom osetljivošću epigastrijuma, mučninom, povraćanjem i leukocitozom od $23.5 * 109 / \mathrm{L}$ upućen je na ultrasonografski pregled abdomena. Analizom kliničko-biohemijskog statusa pacijenta kao i samog ultrazvučnog pregleda abdomena postavljena je sumnja na opstrukciju tankog creva sa pretećim ileusom, usled inklaviranog bilijarnog kalkulusa u vijuzi tankog creva promera $40 \mathrm{~mm}$. Nakon urgentne eksplorativne laparotomije, dijagnoza je potvrđena, uspešno

\section{REFERENCES}

1. Farrell I, Turner P. A simple case of gallstone ileus? J Surg Case Rep. 2015; 1: 1-3.

2. Ploneda-Valencia CF, Gallo-Morales M, Rinchon C, NavarroMuniz E, Bautista-Lopez CA, de la Cerda-Trujillo LF et al. Gallstone ileus: an overview of the literature. Rev Gastroenterol Mex. 2017; 82(3): 248-54.

3. Sahsamanis G, Maltezos K, Dimas P, Tassos A, Mouchasiris C. Bowel obstruction and perforation due to a large gallstone. A case report. Int J Surg Case Rep. 2016; 26: 193-6.

4. Halabi WJ, Kang CY, Ketana N, Lafaro KJ, Nguyen VQ, Stamos MJ et al. Surgery for gallstone ileus: a nationwide comparison of trends and outcomes. Ann Surg. 2014; 259(2): $329-35$. je učinjena enterotomija sa ekstrakcijom kalkulusa, kao hirurška metoda sa najnižom stopom postoperativnih komplikacija u tretmanu akutnog bilijarnog ileusa. Potvrđena je holecisto-duodenalna fistula kao glavni uzrok bilijarnog ileusa. Postoperativni tok je bio uredan.

Zaključak: Prikazom ovog slucaja ukazuje se na enormni značaj ultrazvučne dijagnostike u postavljanju dijagnoze bilijarnog ileusa uz dijagnostički kriterijum Riglerove trijade koji obuhvata pneumobiliju, intestinalnu opstrukciju i ektopični kalkulus. Inicijalno neprepoznat uzrok opstrukcije i zakasnela dijagnoza koreliraju sa lošijom prognozom. Ovaj dijagnostički modalitet može biti sasvim dovoljan u postavljanju brze i precizne dijagnoze koja vodi pravovremenom hirurškom tretmanu ovih pacijenata.

Ključne reči: holelitijaza, bilijarni ileus, ultrasonografski pregled abdomena.

5. Chuah PS, Curtis J, Misra N, Hikmat D, Chawla S. Pictorial review: the pearls and pitfalls of the radiological manifestations of gallstone ileus. Abdom Radiol (NY). 2017; 42(4): 1169-75.

6. Nuno-Guzman CM, Marín-Contreras ME, Figueroa-Sanchez M, Corona JL. Gallstone ileus, clinical presentation, diagnostic and treatment approach. World J Gastrointest Surg. 2016; 8(1): 65-76.

7. Liisa C, Minna C, Hanna MC, Aina IC, Fuju C. Clinical and radiological diagnosis of gallstone ileus: a mini review. Emerg Radiol. 2018; 25(2): 189-96.

8. O'Brien JW, Webb LA, Evans L, Speakman C, Shaikh I. Gallstone ileus caused by cholecystocolonic fistula and gallstone impaction in the sigmoid colon: review of the literature and novel surgical treatment with trephine loop colostomy. Case Rep Gastroenterol. 2017; 11(1): 95-102. 
9. Howells L, Liasis L, Demosthenous M. Gallstone coleus: a rare relation of gallstone ileus. Int J Surg Res. 2015; 2(4): 28-31.

10. Bruni SG, Pickup M, Thorpe D. Bouveret's syndrome - a rare form of gallstone ileus causing death: appearance on postmortem CT and MRI. BJR Case Rep.2017; 3(3): 20170032. doi: $10.1259 /$ bjrcr.20170032.

11. Jakubauskas M, Luksaite R, Sileikis A, Strupas K, Poskus T. Gallstone Ileus: Management and clinical outcomes. Medicina (Kaunas). 2019; 55(9): 598.

12. Rami Reddy SR, Cappell MS. A systematic review of the clinical presentation, diagnosis, and treatment of small bowel obstruction. Curr Gastroenterol Rep. 2017; 19(6): 28.
13. Rotaru MI, Necula AH, Caraiani CN, Badea AF, Tantau MV, Badea RI. Point-of-care ultrasound in management of gallstone ileus - a case report. Med Ultrason. 2019; 21(2): 197-9.

14. Bakhshi GD, Chincholkar RG, Agarwal JR, Gupta MR, Gokhe PS, Nadkarni AR. Gallstone ileus: dilemma in the management. Clin Pract. 2017; 7(3): 977.

15. Salazar-Jimenez MI, Alvarado-Duran J, Fermín-Contreras MR, Rivero-Yanez F, Lupian-Angulo AI, Herrera-Gonzalez A. Ileo biliar, revision del manejo quirurgico [Gallstone ileus, surgical management review]. Cir Cir. 2018; 86(2): 182-6. Spanish.

\section{Correspondence to/Autor za korespondenciju}

Mitrovic Milica

Clinical Center of Serbia - Center for Radiology and MRI

Pasterova 2, Belgrade, Serbia

email: dr_milica@yahoo.com;

phone: +381638064620 